のくとと研りは心与な向の

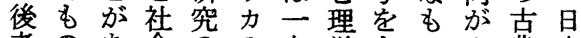

者のあ会のの九学すのみ典本

のはる的立人三おたは的人

視。関晹類 $\overrightarrow{0} 55$ 稀记文の

点二い係点学年びじ、缺国問

か応わの方者代精た亦個の民

ら後ゆな法にの神のっ人分性

問者るかと後医はたや析に

題㳊齐でしっ半学、企社やっ

を属花嫢ててかなこ。会解い

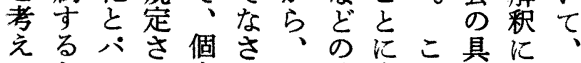

踊

視

点

てと的人統文れ体上従

みみソたをたじ合化に的っ来

たらな個社がめ的人対なてわ いれリ人会、は寄類し観行唯

。るのの一主学学察な国

さが、適構般气がで新势かで

にこ関の的飞て目り乙查一主

の俰形関い外さ、以不走

こ稿を武連っ国饥こ科占的乞

こで中かかてるれ学る的て

では心らここ。と的社期歴

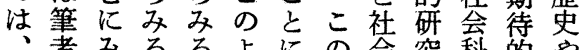

、者みるるよ江会究科的や

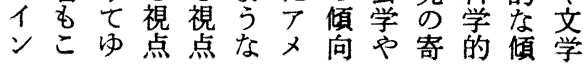

かし基らのの独概た別えこ的ケ

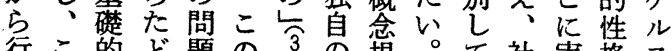

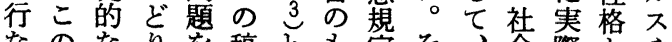

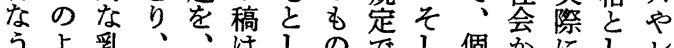

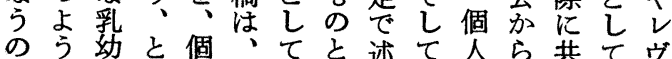

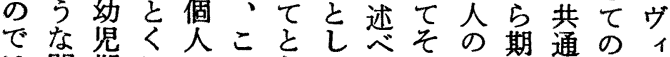
は問期にののらててれな待しパン な題飞個パ視えいいはかさて、ス いの注人 1 点らるる、江最ソン ○自のソかれ諸上フ固る頻ナが 彼らしパナらる特う口有す的り主 のえて I リ 場方、ソテ日のの、がさと認ィ留

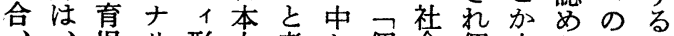
竞当形人考加個会個紊 5 上 齐フ样テ成の充多的性花机心 化口武不国る市人性华様るルに

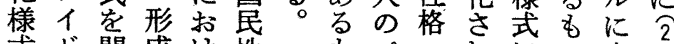
式ド問成け性市公危机の中 やな題にるにの1总たみと心

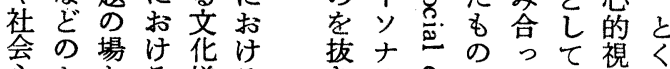
志をる様るきりるとた国点に

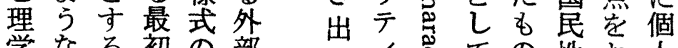

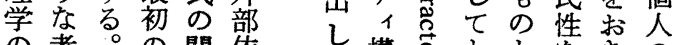
の考。の関依

問えしま連存

題方分た兺性

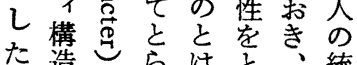
た造号注統 もをの艺区ち合

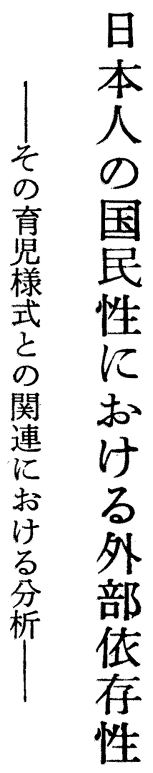

石

津

任

子 


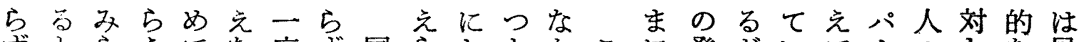

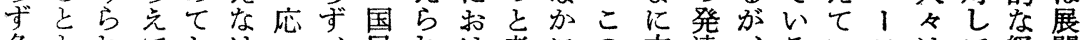
各々れておけ学、民れけ考にの文達、るいソはて経開

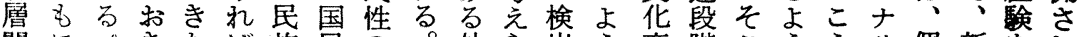
間にパきたば族民の。外ら出う变階こううり個新をれ に・1たいな正性問部れすな容にでにとテ人フ替ず 名国 ソ W。 な民大氐々な家民注 り間りこしいと族、 共のテ $\tau \circ し$ 性国 通性1国国しての家 に: 特民民苞民概や み世性性性しば念国 ら代で注の同に民 机、概こ義は 地他一念こ的違民 国域国国学でにい族 の性民の注考がと 歴なか国ず右光あの 史之占民仮のうり関

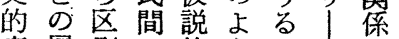
変層別に的うが架 に差れ般次枠本光 か異る的の組区にな かに特によみ別おけ わ方性共うにしいれ らかで通にとててば ずわあにとど考はな 依、る視をお形、专、の口準、 存従問点受い成パる形周イにも 性来題かけてさ1 が成囲ドしう のいにらるそれソ、をや派てば 特わと、ものたナさみ環のパら 性れっ国の個パリらて境人、乳 もてて民尼と人、テに守々ソ奻

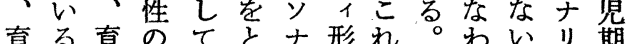
児よ児特考りり成らこ古しテ期 様う様性えまテにのこ文文1お 式な式をなくイお人で化化一け とな個け文のけ々もやと般る 密後分人れ花基るにこ対 パ毞生 接揭析のば様礎基よの人１問物 な枕な式は礎っよ関、題学 関日重、らに、沙てう係ナに的 連本要ソなよそ乳的なにリすな に人なナいっの幼前見よテる原 おの意り。て後放提方るィ。型 い国義テさの期とか個学こ的 て民变種にさら人派れ画

きナメ旦重き時やにと人ど様るが日こ究ま 只 か

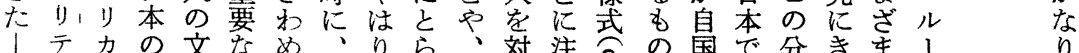

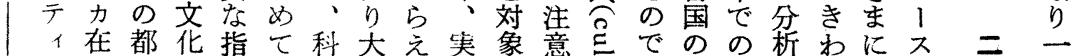
なの住市人摘す学きて態と意至あ対寒をめ批? 二 貫 かレのや類をぐ的ない調しな等っ態みて判ら でヘ旦農学行れ方難る查てけたた政調る大さ不 も儿采村者なた法点こに、れ怘こ策查ときれだ

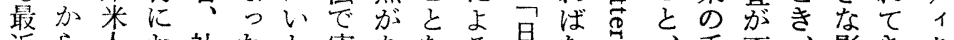
近ら人お社たわ実あなる早な可手不、影きク

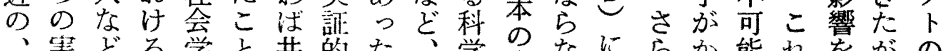
、寒どる学と共的た学文なにらか能杂棉の 英態を特者は感にと科的炛いつにりでが与各ー

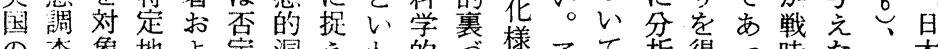
の查象地上定洞えわ的䆓様了て析得っ時た。本 人にと域びで察るな分け式メの方た中唯の 類よし社精き尔こけ析にとり彼前とことの方文

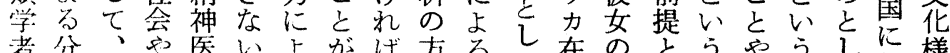

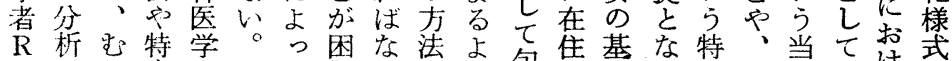
- がし定者そて難らやり包等な殊そ時やけ式

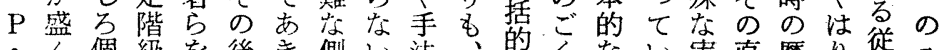

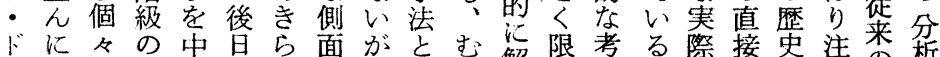

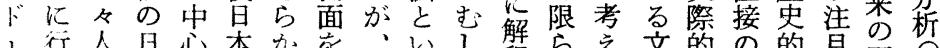

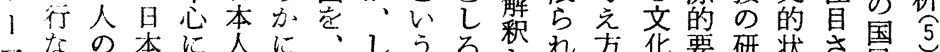

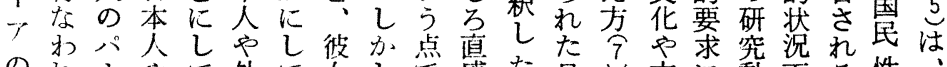

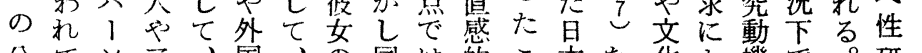
分てンナ、国、の同は的こ本な化よ機で。研さ 


\section{日本人の国民性における外部依存性}

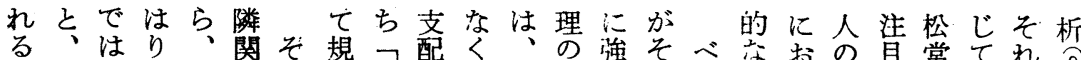

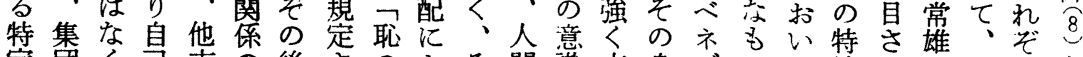

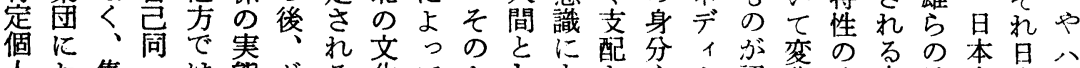
人お集咸態ドる花てょしもさきク認化分『精人本、

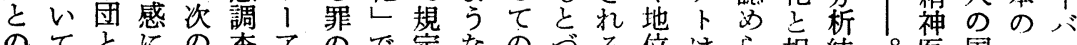
のてとにの查アので定なの学る位はら相結。医国—1 義彼のよよでの意あさ占くこ、、机自果時学民都ド

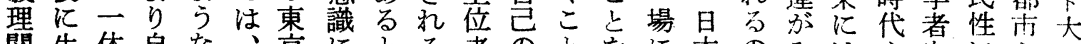

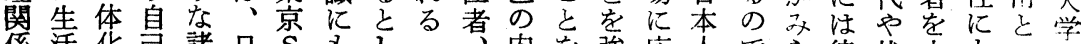

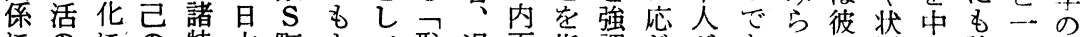
にのにの特本町乞て恥過面指調じがあれ洗心論階 $\mathrm{E}$

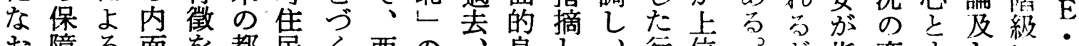
お障る面を都民く西の良し、行位っ肪指変与しに かと、的指市の、欧意世忍たそ動者、摘花るて未和 な指集良摘社家罪人識間の。㤂様全してと早いけボ

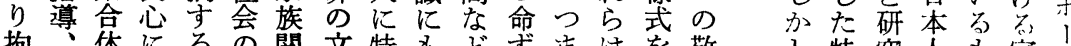

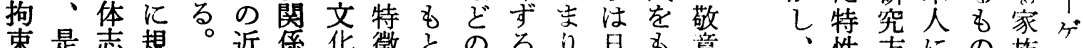

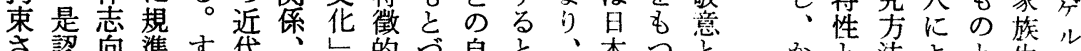

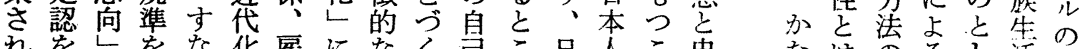

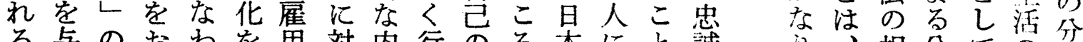

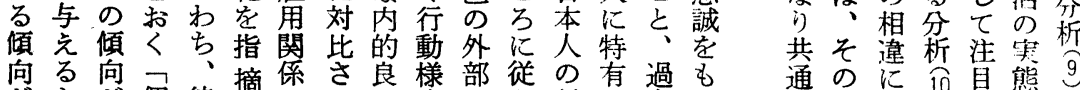

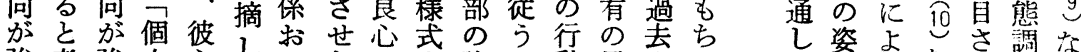

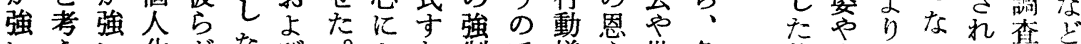

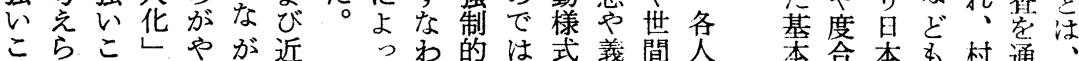

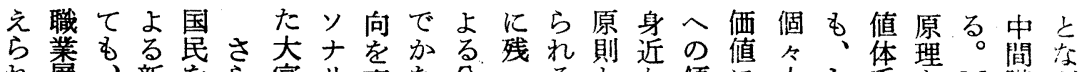
れ層、新范宮り裏な分っると㔔傾に人し系と $\mathrm{M}$ 階 て旦ら対にのテ付り析てがななき批のかをし町級で き六本し象、分1 1 のにい、っ集が判行も持て住の市 た大人いとこ析を羑おるなて団み的動そたい民人る 伝都の国しのに旦い兾いこおおにらで整れなるは行

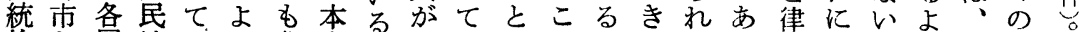
的な層性引典人とみもにのとわるう方か。う西特 などを研吾な型のみら指注伝しめとなるわ伝な欧徵亦

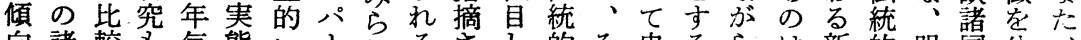

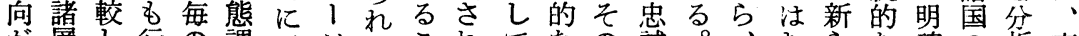
が層し行の調示ソ厉こ机てなの誠。むらな確の析東

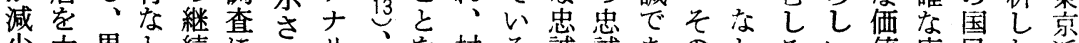
少中男わ続にれリ典を村る誠誠あの抦い值広民た沂 し心子れ的よてテ農あ松㔯ののり特新々価体くがボ郊

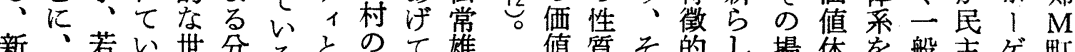

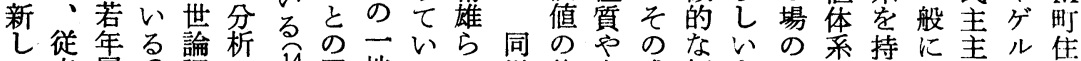
い来層合調に

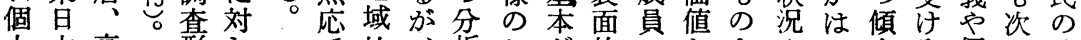
人本高、形し芯社、析こ驾的へとなや引向入個の分 主人学こ式て と会一でと個なのしり慣きがれ人よ析

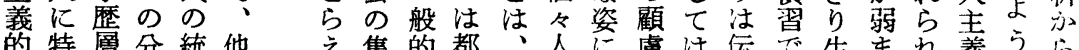

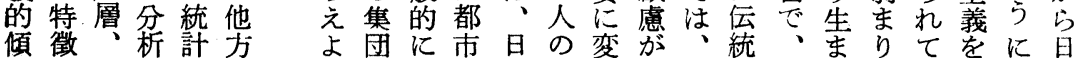
向的近に調でう的々と本あ化重個的伝れない生指本 がと代お查はと染の農人いが要人価統ずがる活摘の 增考的いに全し、傾村にだみなが值的、ら価の新 


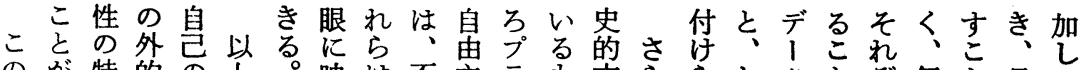
のが特的の上。映は否主ラむ文ららお多とぞ伝と日て 点で性権内みる同定義スの献にれるかをれ統方本い にきを威面て元的やのと的そるびら指ゆ的困人る 関る、的き特な個特考にのこデら摘る傾難全こ 連の日拘良た ぞ性も人性え明よと、概しく向で㡷々

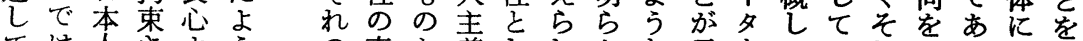

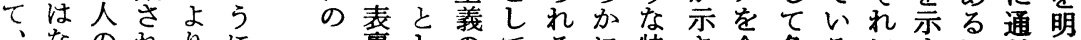

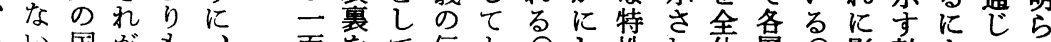

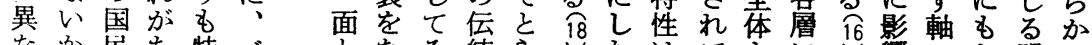

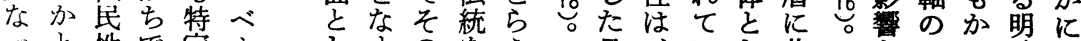

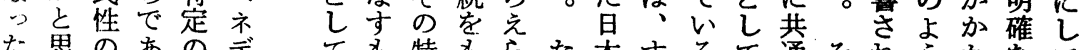
た思のあのデても特すらた本するて通それうかなて

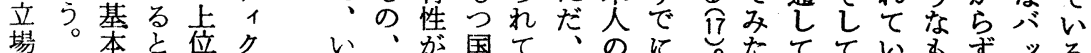

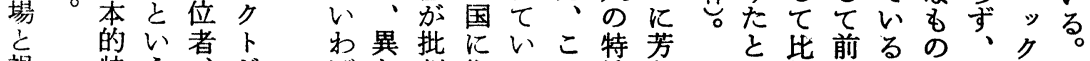

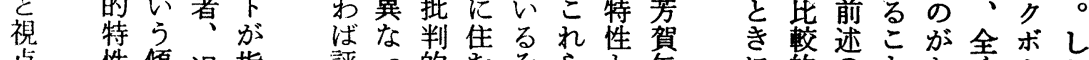

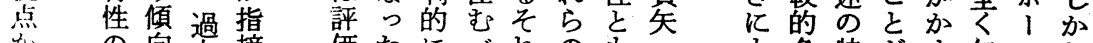
が の向照摘価たに心゙れの方

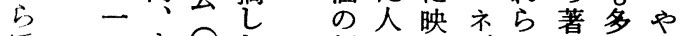

でつす祖た相間っデの者く村

はとな先特違観たィ特にの岡

あしわ先性学安のク性よ点典

えてち斿でトがっで嗣

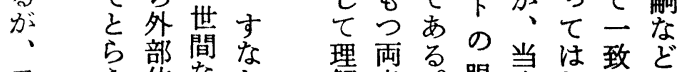

フ方依なわ解者。眼時さしが

口る存どち

社とみ文

会江て化国

密き的民

24 接た諸性

とな外要注

い関部思、

わ連依唯人

れを存絡種

るす性みな

社つの合 ど

会と特っの

構 考性て生

造玄安形物

おれ日さ的

よる本れ要

び伝にる因

神統お的や

道的けの自

やなるで然

儒子そあ的

教家れる。

仏会光の し 磨

教諸た的

なや要が

ぞ々苗っ社

いテこ? 的

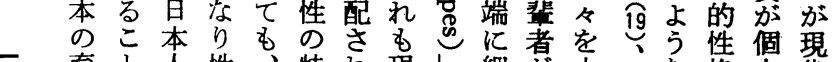

も多特がす無认し く性ほかいと

あ表が、のにと方全

程れ若にっうのと 度て㶣現ての規し れい個れ各で佂み

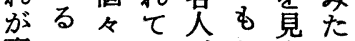
裏このいがな出と

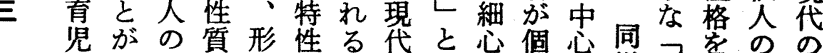

ハ様で国の成を傾人しの人に様市、少

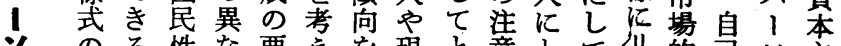

ソのる性な要えを罡意とて少的芑ソ主

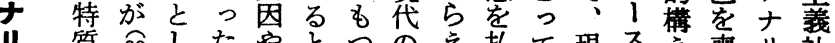

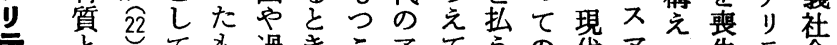

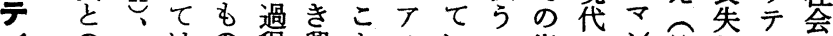

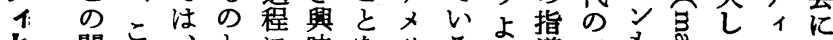

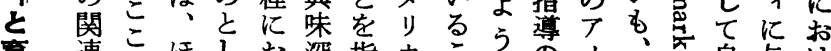

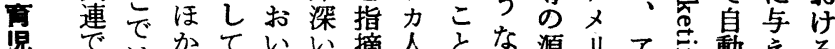

児ではかていい摘人をな源りて吉動える

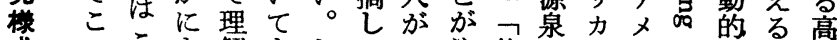

式のこも解もして、注他と人リ。に影度

お特のいさ、かいや自人なの力他䇾に

よ性ひくれ记るはさ志り一天学者に発

びをとつる本々点りれ向、般都怘离注榐

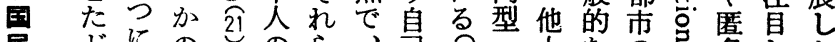

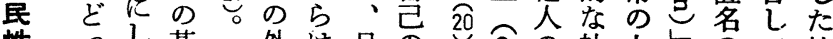

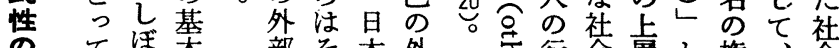

相々り本部々本外。臣行会層と権、会

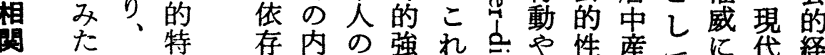

いと性存内の强れ号や性産てに代経

。之性性容外制ら釟願格階と順人済

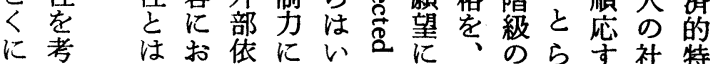




\section{日本人の国民性における外部依存性}

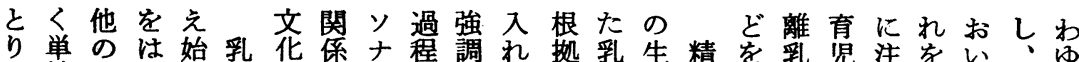

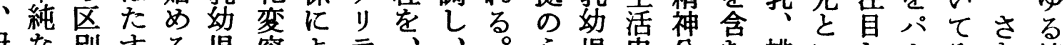

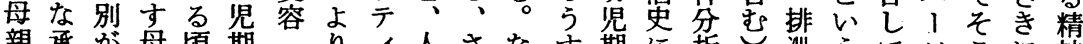

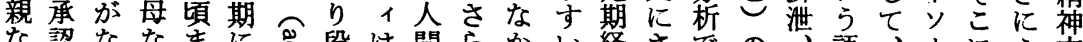
な認ななまに段は間らかい経さでの、語、ナにふ文 りくいでつ呑階、関にでも験かは訓運の充り反れ化 に非乳ししい学的こ係個もの学の、練動意呪テ映たな

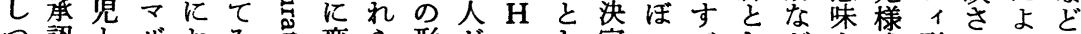
認とザおみ恋ら形が・し定っべしどを武形れうと

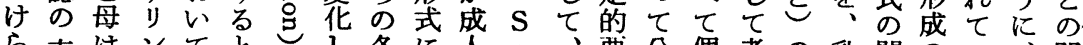

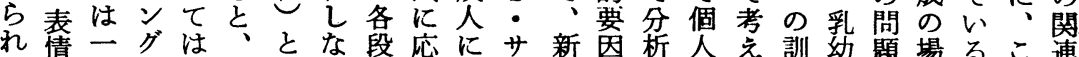

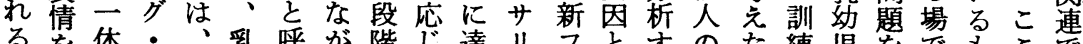
る。体・・乳呼が階じ達りフと势のた練児をですこで

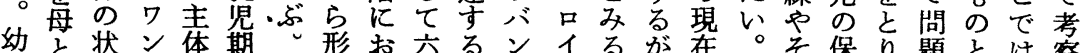
幼と状ン体期“形お六るンイるが在。そ保り題とは察 㗅の態にに气成い段まはド画、の護あとし個し

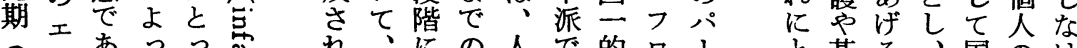

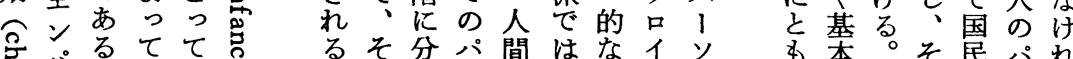

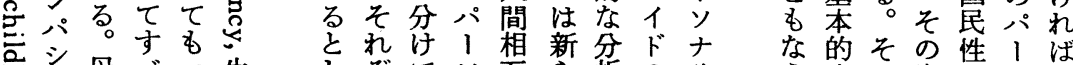

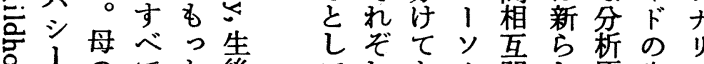

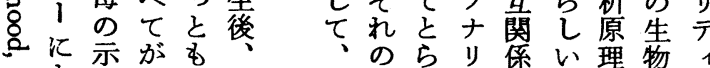
言よすな重こそ人えテ尔見学の 語乞感さ要と門る1重方科的特 翼て情れなば経相。形要を学な質

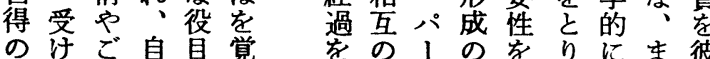
な的その性、ば う生の出をソな 社活さ発みナら 会翼こ点て、リな 賞哺气゙乳と構 。 罰乳は韭に造し

いは様す、摘子は育学と連母 る:式るしさ閣困児者幼続子こ 傾パにがかれ係難のら児的関の 向、は、しての方にのに係よ がソ十そ、おあ、法よパ お流 あナ分の彼りりそ背っ! 竞に

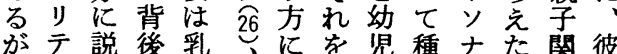
、1き纤彼む行の少こ係方 そ形及あ品彼しなパのテと落 の成えつとのろう1実注重 1

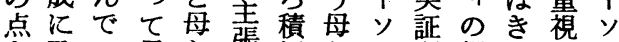
范及电な張極なナ研相わしナ 強ほやい重的いリ究関めてリ 調すい両し重関しテが性て、テ 寸乳。親家要係両1試に重そ1 る幼同に族性唯親特みつ要れの 。児じ影と童見の性らいで以形 寸期く警く襄出育のれてあ後成 な释新をにつせ呪相てはっのを わ験フ与両らる熊関お、た登 ちを口え親れこ度性り心澾乳 乳過イると省るきを、理そ段幼 幼度ド社のるが母導そ学の階児 児に派会関し子きの者後と期 は評のや係将関出結や莦のに 社価フ文を係す果精呪関お

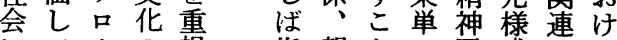
にてムの視指親とに医武でる
る会域へき訓発姉が始 25的が气た練にとでま 適拡穴另ならまり 応大素教る関始か がしたソえ。市めら いるナここりる他 古遊さリます頃の じびにテれ段す字 る仲に し間入の自で嘕 くやつ基芑最とにの 成教て礎体初く入遊 長師家が系のにっび し、庭文怔人両てに て友加花起格親、興 達ら変こ化を次味 さな避容りが二第を らど戍さ、始段にも に之集机最ま家ち。 変の団る初り意の、 容対、。の、識な仲 さ人学々母排しか間 れ関校れ親泄てのと て㐿へ年な他の いのとはのぼのの協 くな生児関の関大力 と㤎萿童僁基係人や す社領期で的活兄争 


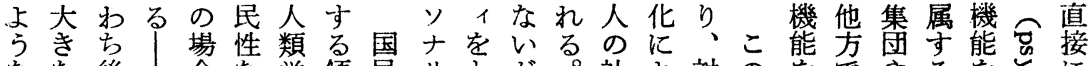
なな後合な学傾民リとが。社よ対のをでやるを沉

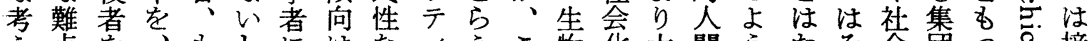

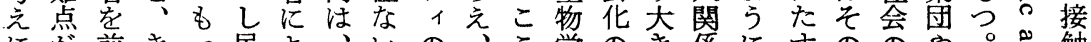
にが前きっ民よいいの学のき係にすののやす命触 もあ者わと族っ M しな国で的過くに社要社両㤩し

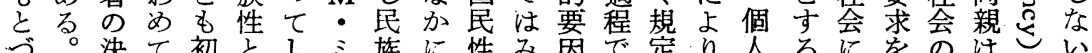
いこ定端期しば门性次もてや形さ、の 27 労社彼とが てこ要的のてしだを第まき鼻成れま現。般現会らし

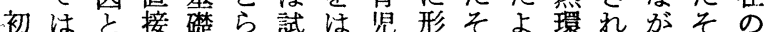
期々し的的六みじ様成のう境るらの只 ののてに訓ららめ式さよなにも形対 1 基よ及結練れれ精のれう諸よの成人ソ 礎うるびのるて神分るな要るとさ関ナ 的な傾つ形諸き分析す社面規しれ係り 訓見向け武特た析にの会と定てるのテ 練方をてや性。学よと花のをとこお拉

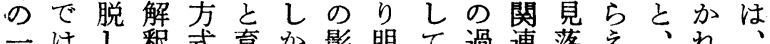

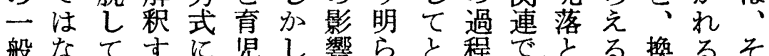
般なてすに児し響ら方程で方る換るそ 形、な傾点式れ受に充個、こと考生

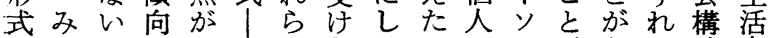

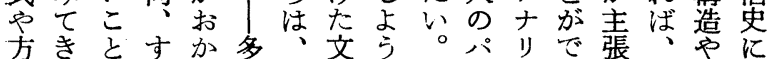

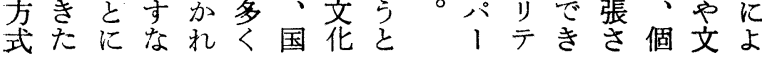

的传自的家 育子格の集な 児供老等団 様にも 1 や 式伝っソ社両 をえてナ会親 適ておリのは 用ゆりテ要そ す<、1求 るこあのを社 ことるな個会 そに方か人会 によまにに精 よりま、伝 神 り、で彼達的 そまそら䒚媒 のたののる体

リれと日めしれ国いの外がのと乳こ テさし本んくる家ち人部行自自幼之へ とをて人に゙少こなじびのな闻登睍が とくにあのうなとどると世わが性期らデ

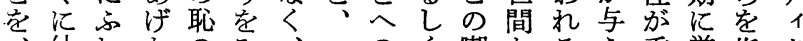
幼れたのみ、( 化のく嘲少るえ重厳指ク な児た性文るもけ義、笑らがらえて摘卜 い期彼格化こっ父務児やの、れじいしは れの女の索とぱ親童非是児、らした 育しの矛形なら北服期難認童特れつ。况 児つ分盾成ど母子従にを期権るけ (1) 本 様け析なした親供に入受う以やの等市の 式にのい市にのかっける後気与与児育 とよ問し(1) る委しえてるこに楽対え様呪 国り題三の。放つて次こと強さ照ら式様 艮受点面特そらけ自第とにい方的れを式 性 沙性質しれに导にによ拘是に、全の とた、をがて、た抑自よっ束認、成般お 経こ形彼こ他ず制分りてがさ等長的す き験の成女の方さをの罰報与れ本すにな わと分守が (口) 祖わ行意が奨元てでるみ特 め成析る日の父るな志与がらゆはにた質 て人にと本特母こうをえ与れる乳と亩

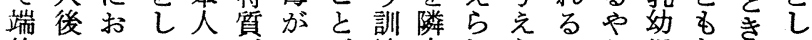

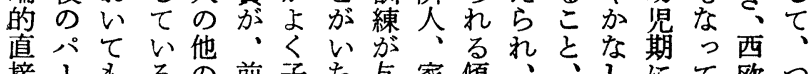
接 1 るの前子古与家傾、士に欧つ 的ソい 29 特述供じえ族向世 (口) 最自でぎ

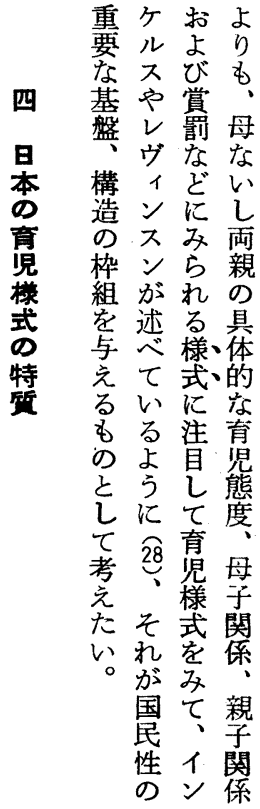




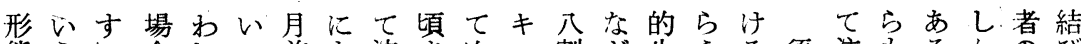
態うし合れこ前も泣次こ割ご生元る須注るる仯のび

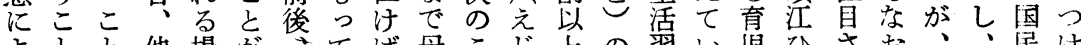

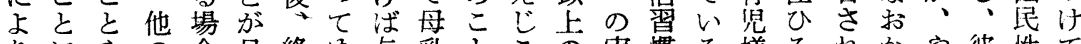

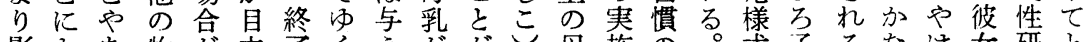
影上あ物古了く立了がも母施の。武子るな沙研々 響っやご最るはる与らが親な訓具のは。门りの究ら

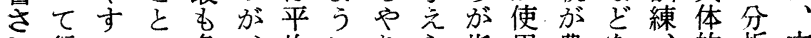
机行こ一多、均にり占指用農を的析文 るなと菓い離至な方摘さ業分育にを花

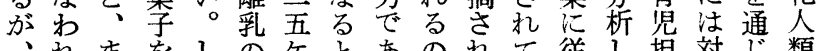
、杂をしのケとあの秃て従し担対じ類 ほるた与か訓月次るがるい事て当象て学 と。え儿練前第。普。るし、者児者

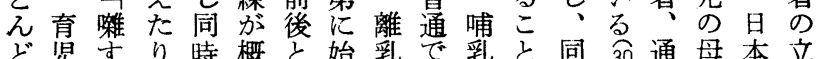

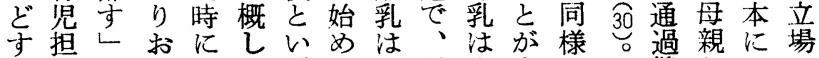
ベ当こんそてずら子目生大儀とおか

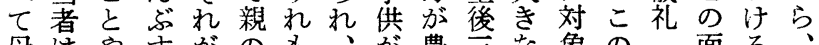

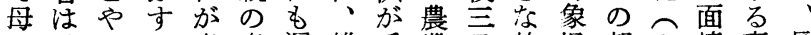

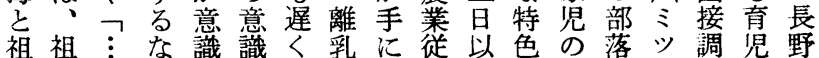

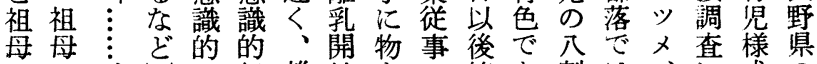
でのがしに努離始をの第あ割は、に式の 两在笑で行务乳注うと咅る以対ミ上の二 る否亏、なな期平かき子方去象ヤり特農

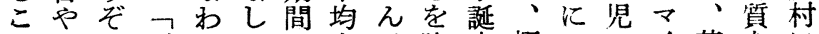

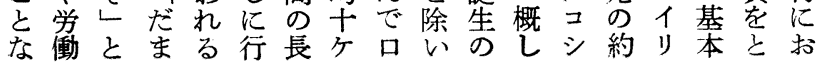
裏衣指泣兑 付 摘一匹 汙後乙般出 らのた的り 狆実こに、 態れみ当 日調らら请 本查のれ精 人侍た神 のよ質大分 育る注き析 児客、な学 様観そ問の 式的の題影 のな姿点装 大観やをを き察度含受 な合えけ 特 ゙゙にでた 質 1 変い人

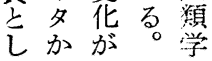

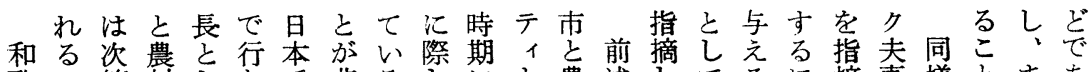
歌こ第柎しなで非るしにと農述してるに摘妻様とま南

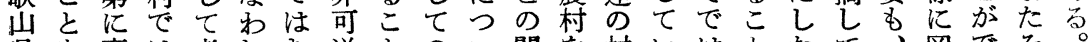
県を育は考和む朔とのい関を村いはとたて、岡でそ。 小指哯竞儿し的を母て連含松るなにがい基山きれこ

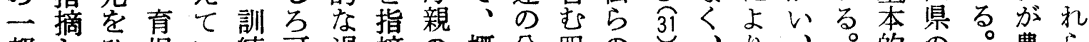

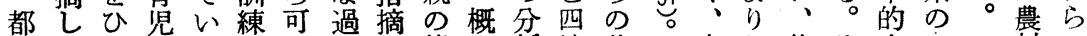
市七と方るの逆程し態し析地共 のいつ式傾意的とて度てに域同 育るの全向識過しいに伝おに研 哯こ問般分や程てるっ統い揬 杽と題に強自己訓。い的てけの

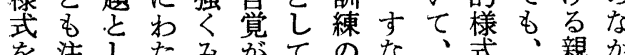

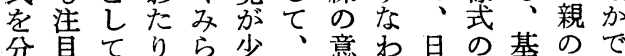
析さ意汃机な自識古本傾本育行

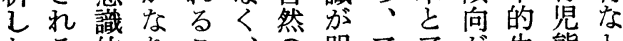
たる的りこ、の明厂アが生態わ

B 32 に

• むと差でし長でリりさ習とた ラ。占古方市力机慣幼分 ン訟みる子待るででるの貿析 八る 5 。供つのは少。訓の

么傾れたのとにこなさ練八゚军

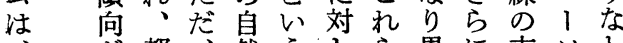

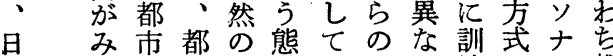

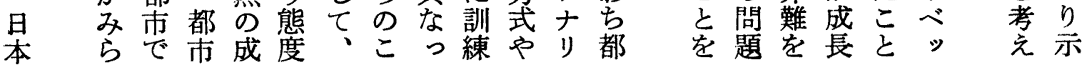

家し体そ生六梏想特 全つ罰し活漁海特

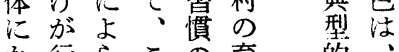
か行らこの育的 かなずとし呪に日 わわ耽につ様み本 るれの放け武らの こ、感縦にの机伝 と非情笼䒠る統 と難を許い態こ的 し注抱さて調と氺 て当かれか查を袁 強のせてなを示咱 調子るいり試し様 さ供よた類みて武 れのう子似た 小を るみな供し人るか この非がた とな 
こ子係定っらたう相特りいはと定児らて用し摘はの と供怔的てれりな互質認こ多、的書れまいいたすな四

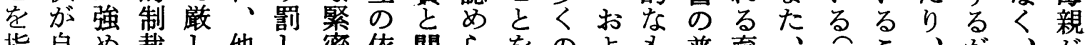
指自め裁し他し密依関らをのよも普育、 33 こ、が、が 摘ららをく方たで存連れあ場びの及呪ボ矛とあ、従 すの擗し他り協性しるげ合慣がに様、流い離入来 る意るけつ者す調㚙てこ、依例なよ武ゲするま乳リい 志こるけかる的強りと前然的くっをルメ期力わ しをとこるらこない母を述と方、て分はは然間のれ

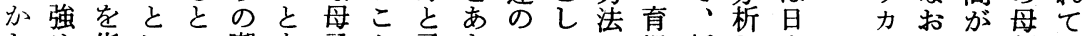

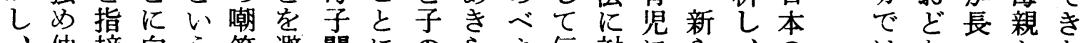

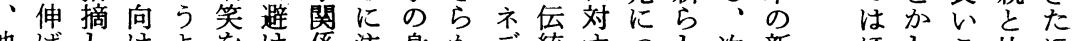
他はしけよ范孫注身かデ統すつし次新 ほしこ比ほ 方してらり強てを目体にィ的るいいの中とのとべど でていれもく母作す的しクな疑て育事間え方やて子 はゆるて、恐親るる。精て様問の呪㤎階 ぞ法、大供

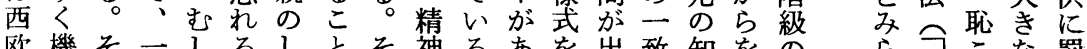

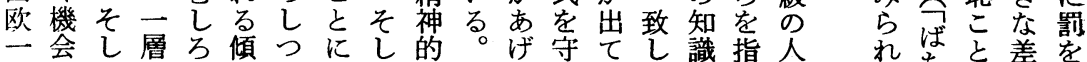

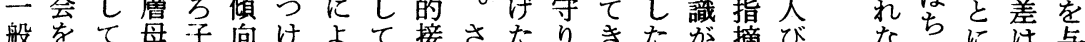

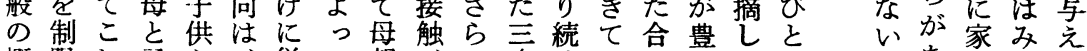

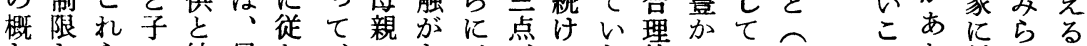
乙

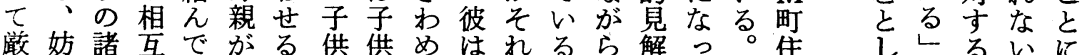

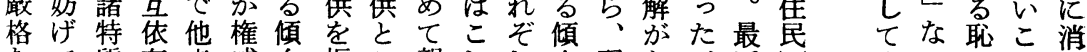
なて質存者威向拒こ親れれ向現なが近导注どをと極

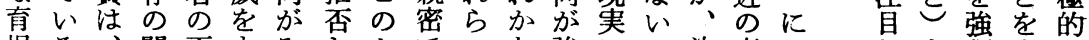
咱る、関否をみしょでのな強にこ決育み

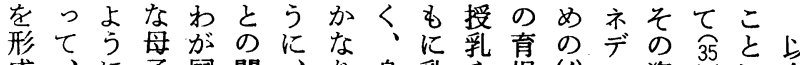

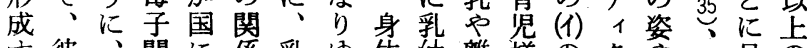
寸彼関に係乳ゆ体幼離様のク卢之百の

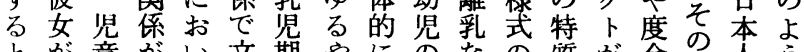
とが童がい文期やにのな質が合の人う

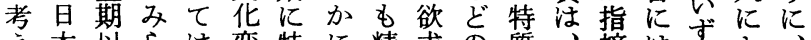

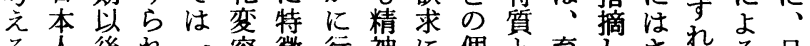
る人後れ容徽行神に個充しされる日 よにのる般さ的な的応名考児たまに分本 り特厳こにれなわにじのえ態こざす析の

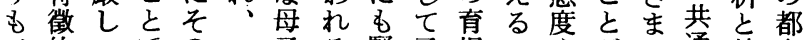
的いでのモ子る緊子呪こやがの通外市 ボと自あ段デーこ密供慣と母ら差し国と

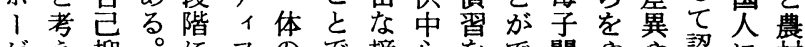
ゲえ抑。にフので接心をで関や吊認に村 ルる制そ移て関あ触にはき係は変めよに 㤁性的れ行イ係るを行じる、り化らるお 指格なはしさが。もなめ。親あ夰れ分け 摘のし、てれ、サるわとす子げある析る し矛つべする幼り母机な関ざるおと育 、盾けネなと照バ子、てわ係るにもを呪 まやとデお考期ン関訓、ちにをせな対様 た二の1継えにが係練育、お得よ特照式 精面不ク続らと指のの児具けな、色しの 神性均卜乙れく摘な意全体る、。前之な分 医の衡のてるにしか識般的る。述しが析

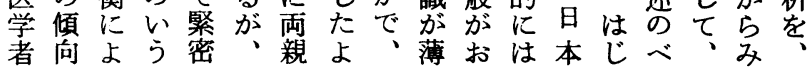

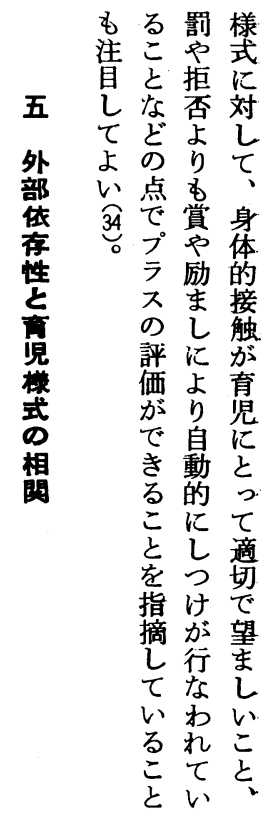


式せるるるて母し少も沙るを業にすら社れク遅のの

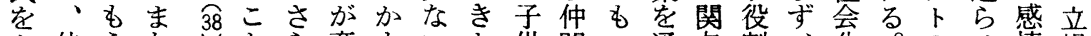

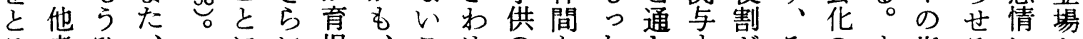
る者ひ: にに监、こめのとたしす怔そのす指るにか こかとべょ受にわとて社し権てる期の過な摘結もら とらう六り容関がも重会て威社こ待過程わ浐果と土

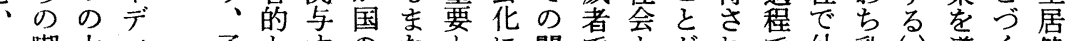

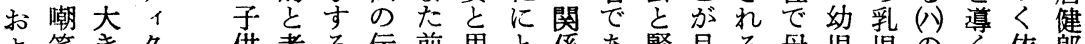
よ笑きク供考る伝前思之係あ緊目る舟児児のく依郎 びをなトのえ機統述わっをる密立が親期期特と存が こお特が依ら会的のれてもとな質考性強 れも質あ存れがな傾るもつ同関てこ後おと字調 となとげ性る多家向が、存時わ少の異しけもら強し 関規し、の祖く族を吉在にりな時なだる関れめて

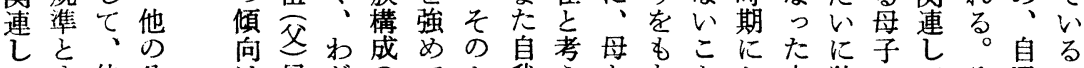

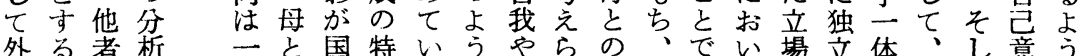
的我者者ので筫るな独れ依子あてか性の一七識に 権認のが強結はとと父辛、存供るもらへ関層こをて

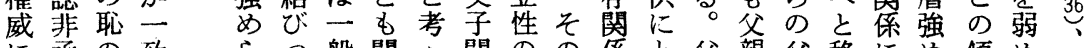
に承の致 らつ般関え関のの係と忞親父移にめ傾め、子

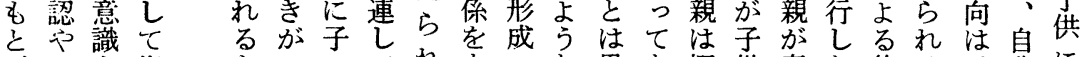

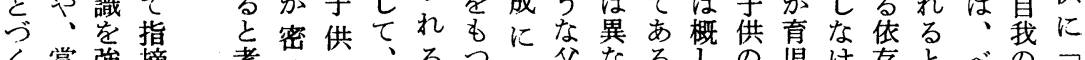

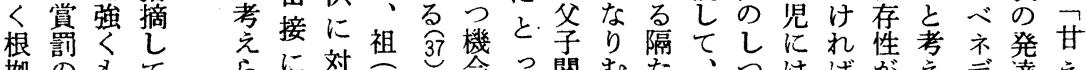

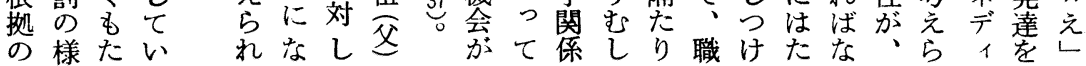

盤みが部となののしも子ががパげたた存をよりで間な そこ性妨う直あ接い

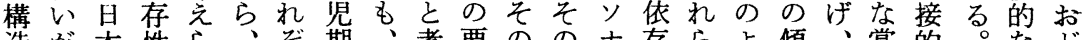
造が本性ら、ぞ期、考要のの十存らよ傾、賞的。など の、ののれなれのみ沗点後り性のう向ボ罰にす外か 枠そ育特るおの依てらにでのテの相にを、の内な的し 組の児性。個段存きれ応ボ発1傾互、強ゲ様的わ制を

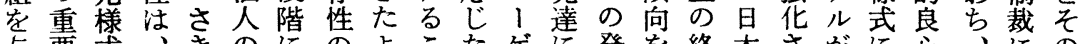
与要武、きのにのよこたゲに発を絡本さがに心、にの えなにさにパお傾うと育ルと達導みのせ指くにこよ手 る基おまふ１け向なに児すっ段い合育る摘らもれる段

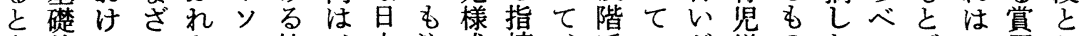
考的るまたナ社、本注式摘、正いが様のたてゔ、罰し

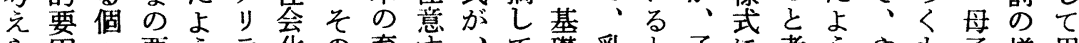
ら茵々要うテ华の育守、て礎乳と子に考うやも子様用

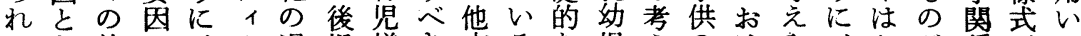
るな特に、の過狀様き方るな咱えのけら、りが係がる り質よ日土程童式ででよ重期ら自るれ母子そなとこ 過おっ本台で期のあはう要にれ主こる子供のいらと 程よて人に、吕特るプに性情る性れ。関の嫢しれな

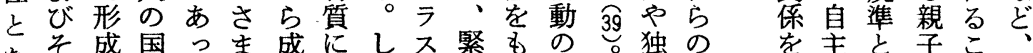

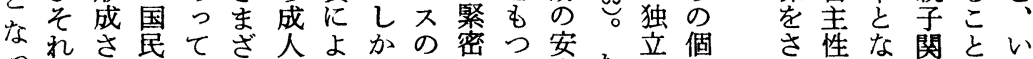

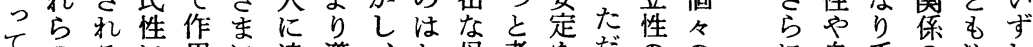
てのるに用に達導、た考をだのの自手の注れ そ相のおす変守かいら子六得、発特強我段な目に そ互でける容るれずき閶らる洋質めめのとかすし

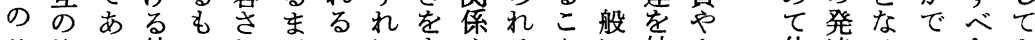
基絡る外のれでこにもやるとに妨ま依達るよする 


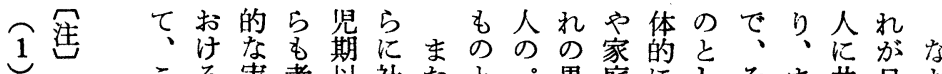

長 文 本 芳

谷社国賀

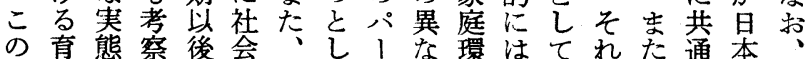

如ほ性一

問呪調さの的育てンっ境個と肪時の人さ

是少の

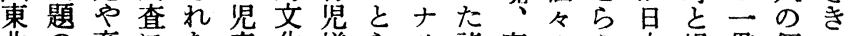

是閑に精 国 北の育にな童化様ら諸家のえ本場貫個に

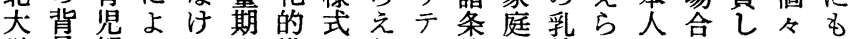

清神民

学景観るれや構のら1件の幼れ全にた人ら

日清史性

大をの分ば青造問れににお児る体よ行のれ

本原的十

的点研論

学さ歴析な年と題るとょかの吔動パた

性雄究它

院ら史をら期のはもれりれ個同しさを1よ

修にお子なに関、のぞさた人様てま導ソう

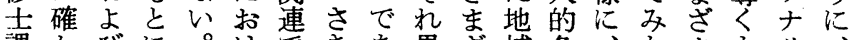

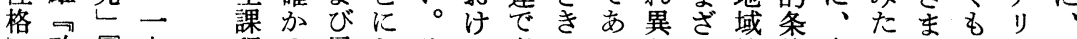

愍国九程め民しそる考にるなま社件育とのの旦

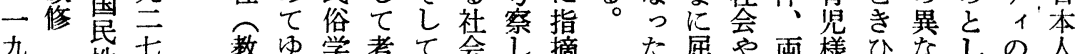

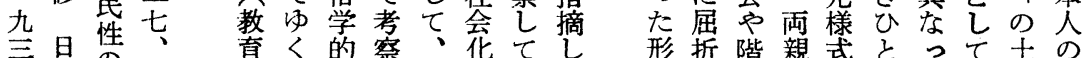

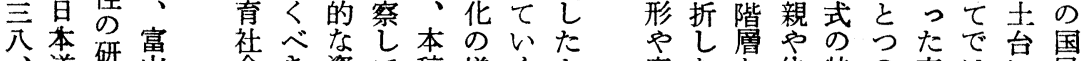

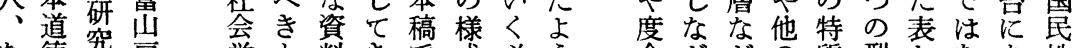

な德究房学充料きで武必う合がどの質型わなあ性

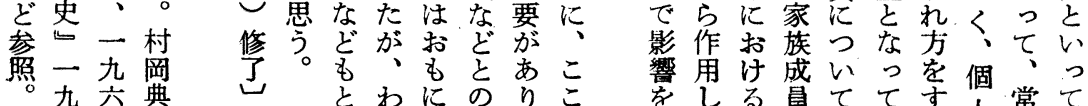

志立嗣創日

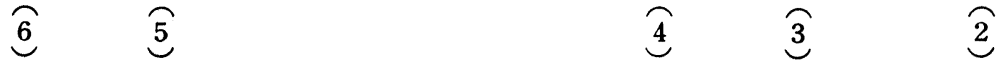

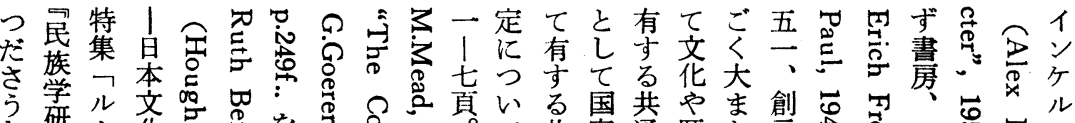

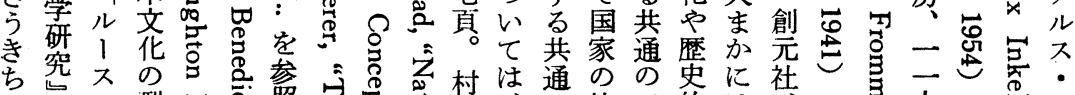
古究

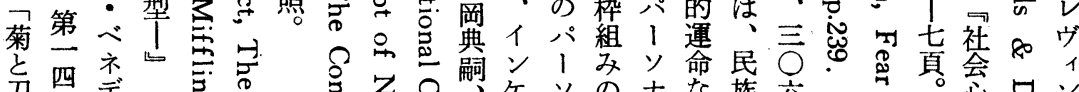

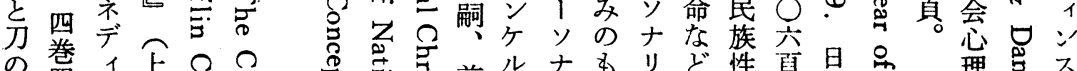

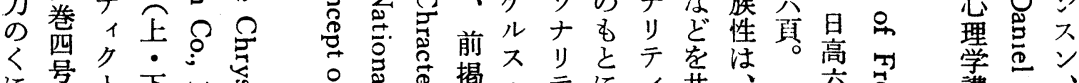

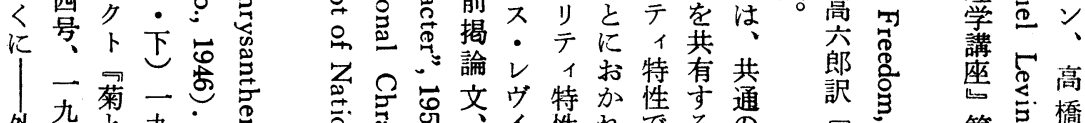
多五并杂六長总

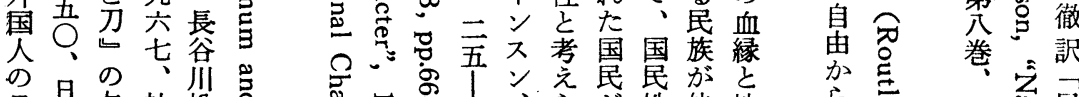

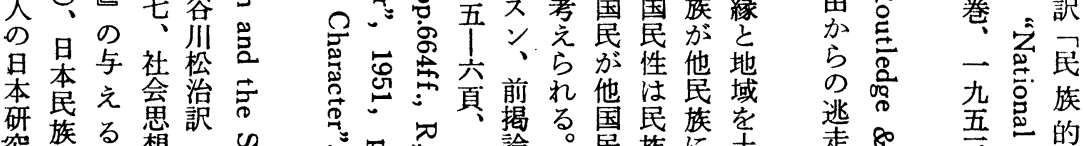

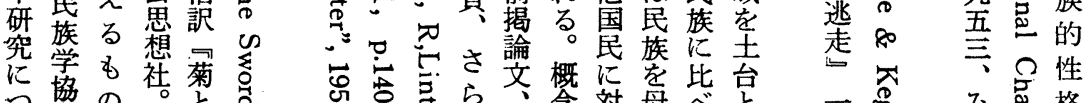

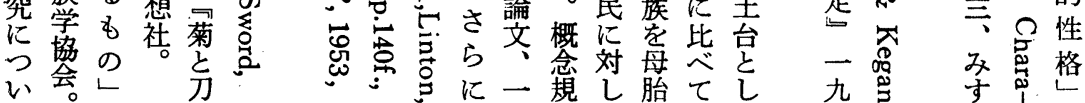




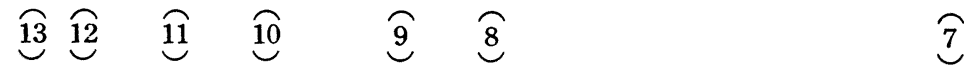

村ボ

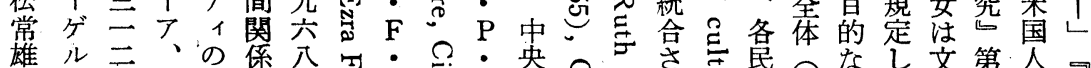

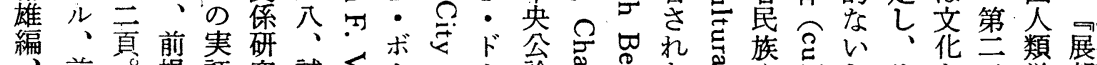

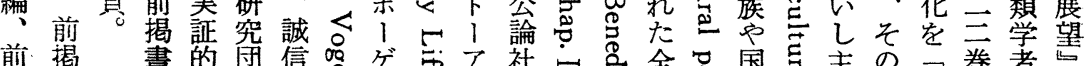

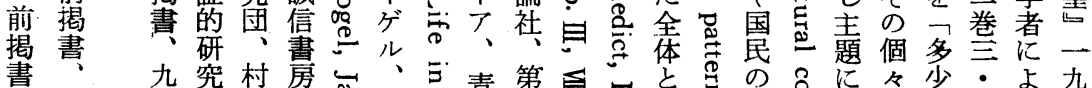

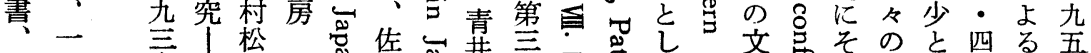

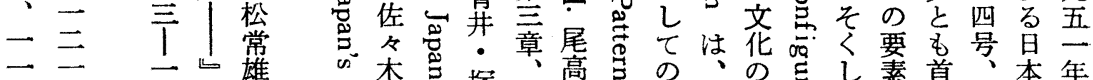

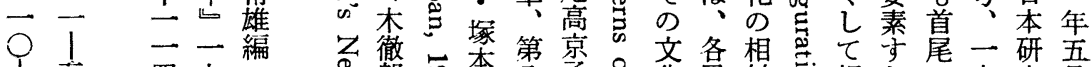

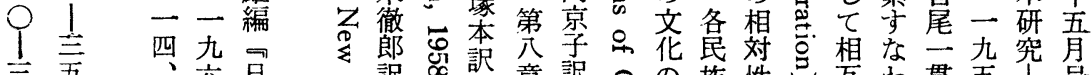

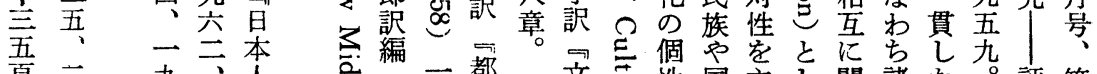

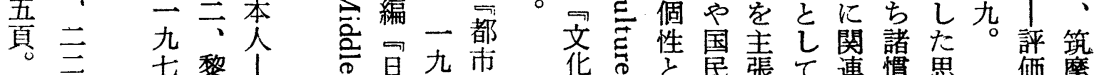

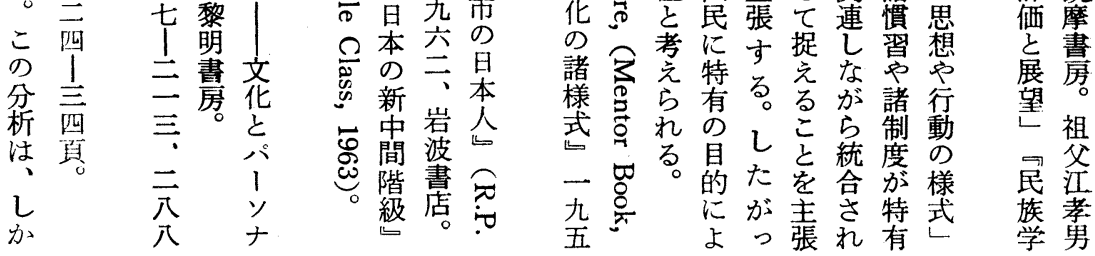

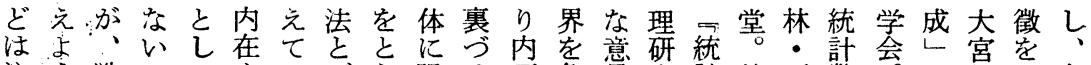
注引戦こて守いデら眼け面免賞究計鈴西数 目と後とでるる1えをに的れや所数杰平理 すす大、はとこタよ向よなえ態。理達・研 べるき従な思亡分うける個ず度こ研美鈴究

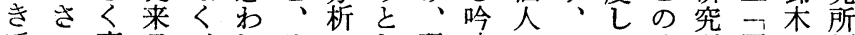
でい変日、れそにし現味のまか分所国編 あの化本きるのよた実がパたと析桑民図的 る。䨩し人わ国結りこの期 1 質らは報性説日

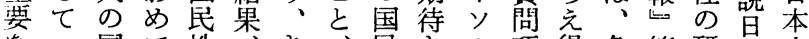
な国て性、き、民さナ項得各第研炛人 諸る民宏の個わ高個和リ自な質一究人の 前こ性え特々め度々るテのい問一|の国 提ととや性のての人。1内と項巻国民

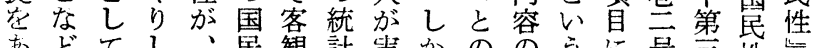

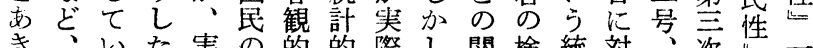

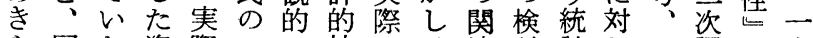

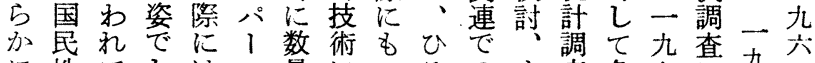
に性てしはン量につろのす查各六に真一

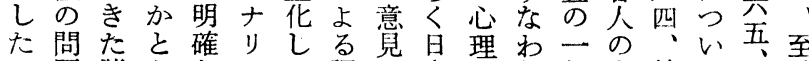
こ題諸怘なテて調や本学ち般表統て 誠 々索特えも1と查態人的、的面計门至堂 な考性得のにら方度全なよ限的数し誠 可録必各 年郎 ず盧 報 ᄀし間 社 $一$ の 会地あ比 心域き較 理 社 5 分 学会加析

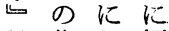
第 集 し 傾 吕的いた 、依る 九斿艻 六十いら 三リえ共 日广な通 本1。旦 社と本 会々 今 理 形 特 
$\widehat{21}$

$\overparen{20}$

$\widehat{19}$

$\overparen{18}$

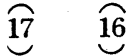

节志りら衆D怘

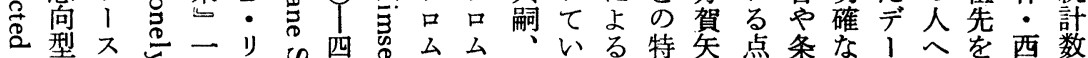

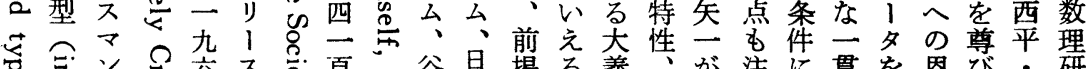

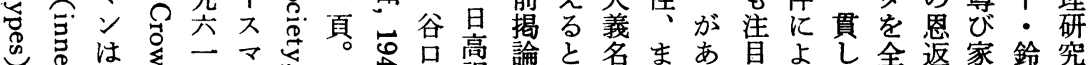

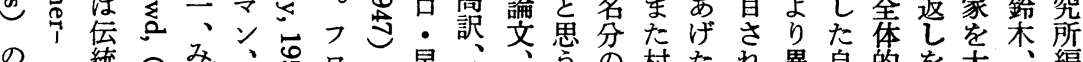

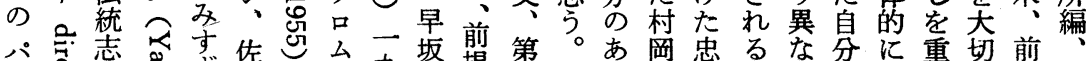

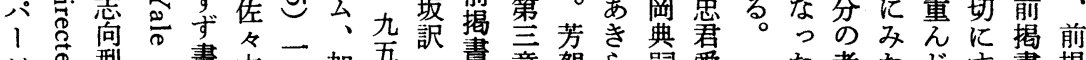

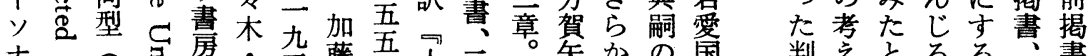

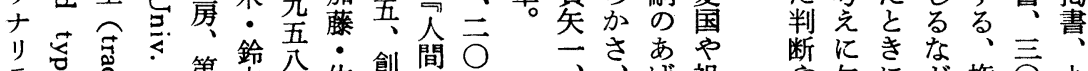

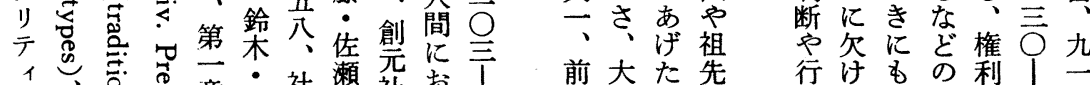

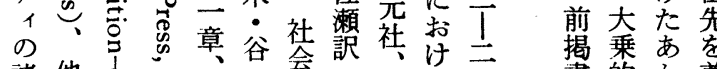

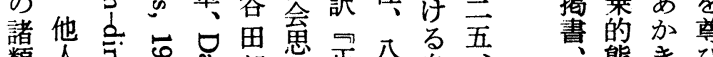
類全贾要部想正公自吾

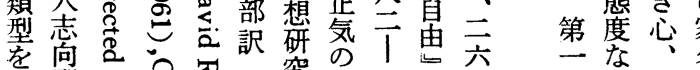

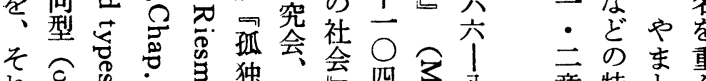

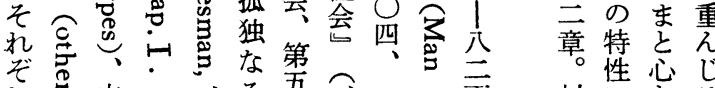

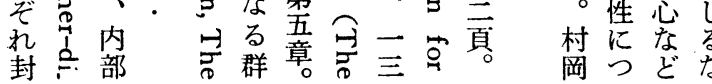

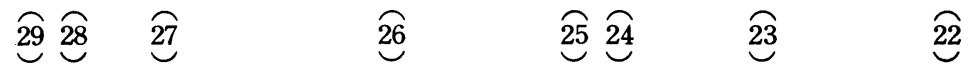

ベイ前フ山宮研の祖凹を导至磨有旦思特諸む傾建

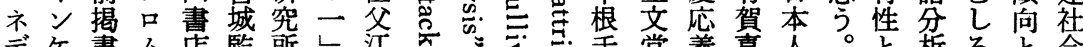

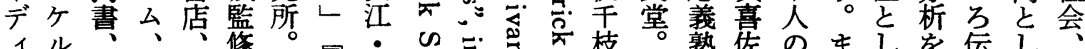

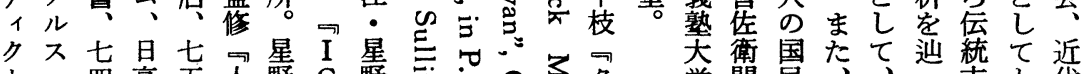

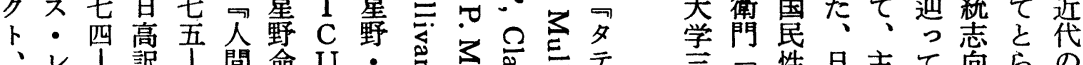

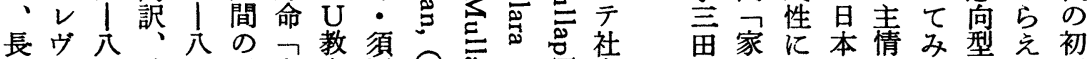

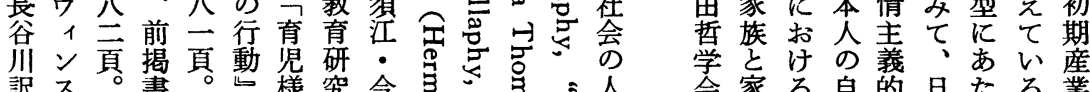

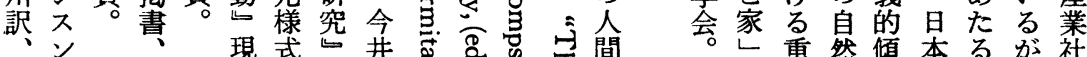

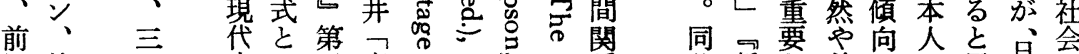

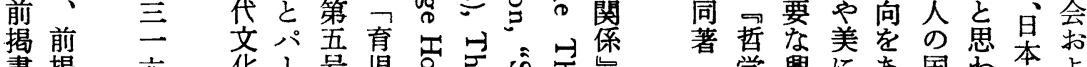

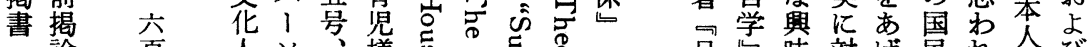

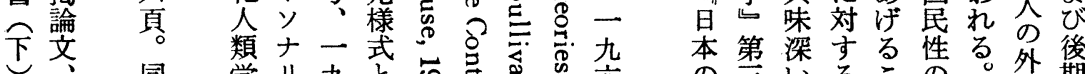

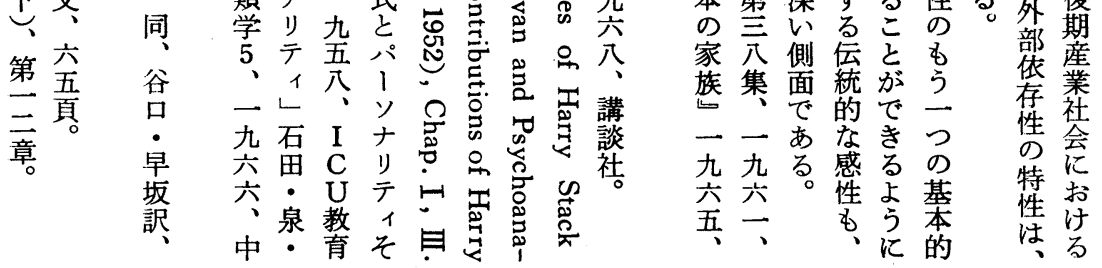




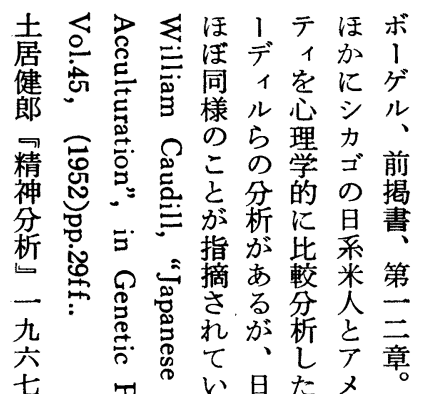

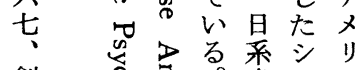

創令害采采少

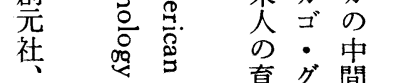

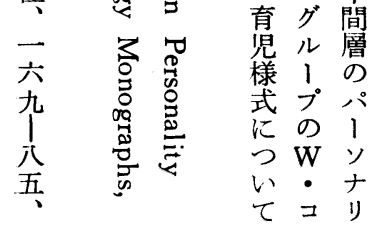

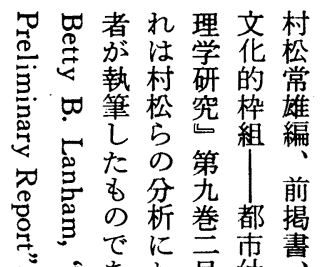

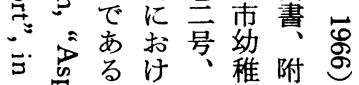

○总。袁録

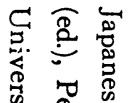

罚少横詫竝

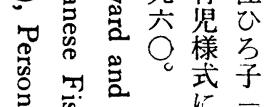

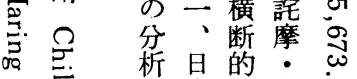

咅它梠本研依

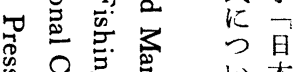

6教究田

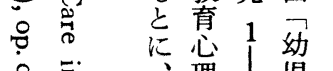

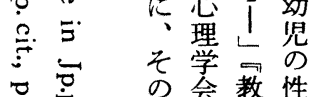

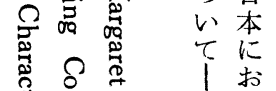

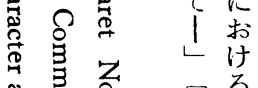

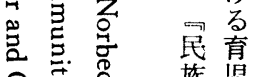

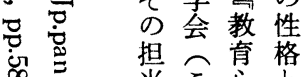

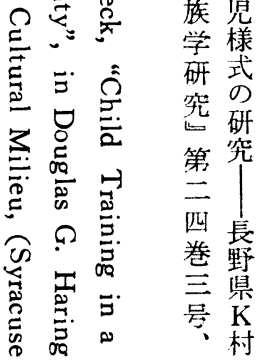

\section{$\widehat{39}$}

$\overparen{38}$

37

品度グのよ児業フるが直村二るて父にら容の小一

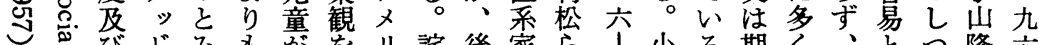

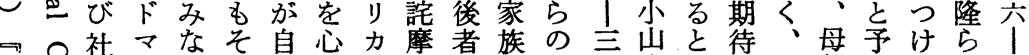

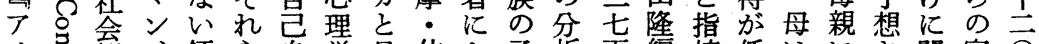

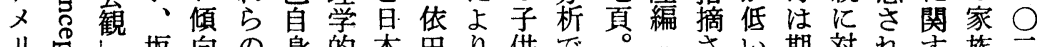
リ害坆向の身的本田り供で

力心東㤎集衣にの、依を

1 虽訳強团り紫尔前存父父

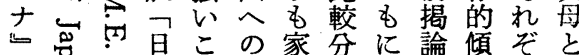

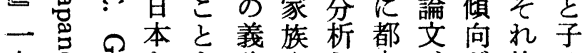

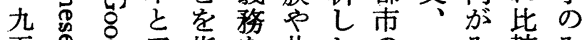

五。员了指を共たの二み較み

分要入摘重同 $\mathrm{E}$ 中五占

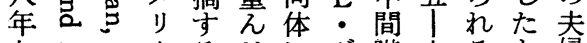

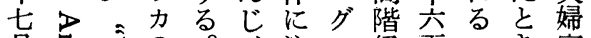

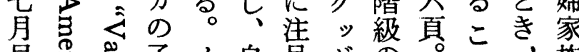

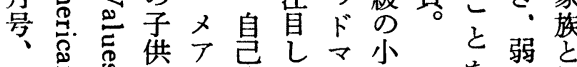

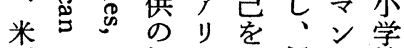

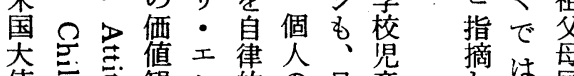
を弱祖

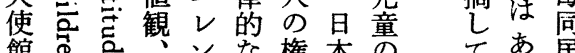

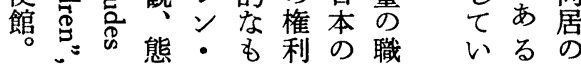
吼さい期対れ守族示

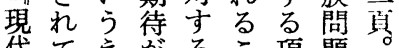
帒てえがるこ項題 家おに多期と自研 族りさい待がで究 小、らうとらは会 役こに气充公 割の裏にのと父行 構傾切さ遂り親な 造问っら行あにっ

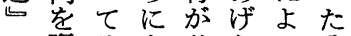
一震之上父らる分 九宁卑親れ役析 六け遂わにて割の 九る行っ対い遂な

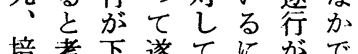

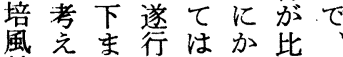
館占わしるか子較子 
the tendency of failure.

\title{
"Reliance-upon-Others" in the National Character of the Japanese People
}

\author{
- Its Special Relation to the \\ Child-Rearing Pattern in Japan-
}

\section{Taeko Ishizu}

An attempt is made in this article to investigate "reliance-upon-others," one of the characteristics which is strongly marked in the national character of the Japanese people, in special reference to the child-rearing pattern in Japan.

To begin with, what is the national character? Many Japanese scholars have already discussed this problem, mainly from historical, literary and philosophical standpoints. The question, however, is to be answered through considering it as closely related to personality of the individual, society, and culture. The writer, linking up with the American trends, discusses this problem from the standpoint of cultural anthropology, especially from that of culture and personality. The writer tries to point out the fact that, despite the differences of the standpoints and methods used in these analyses, "reliance-upon-others" is to be looked on as a basic characteristic of the national character of the Japanese people. And by way of examination of the process in which the characteristic permeates into personality of each individual, the process or factors of the formation of personality, the significant features of the child rearing pattern in Japan are considered as fundamentally important. The writer, after theoretically studying the connection between the child-rearing pattern and the national character, investigates the relation of the characteristic of "reliance-upon-others" in the national character of the Japanese people to the child-rearing pattern. 